\title{
10. Two period pieces
}

As mentioned in the Introduction, these two final pieces do not fit neatly into the previous sections of the book. Although they were prompted by contemporary developments, they cannot be easily related to specific events. Since both have been widely referred to by other economists, it seemed appropriate to include them in this volume.

The first of these pieces was published in the Lloyds Bank Review of October 1982 as 'A new approach to the balance of payments' and is republished here under the more challenging title 'The intelligent radical's approach to the balance of payments'. Its key message is very simple and may be quickly summarized, as follows:

Where payments imbalances between countries reflect the free decisions of private sector agents, such imbalances cannot be a policy problem for governments. There is no such thing as a balance-of-payments problem between consenting adults. Payments deficits may nevertheless be a genuine policy problem when they are due to excessive budget deficits. The implication in that case is that policies specifically aimed at the payments deficit as such (like tariffs and quotas) are wrong-headed. The only cause of an external payments problem is mistaken fiscal policy and the only remedy for it is to adjust fiscal policy.

That may sound straightforward, but it has drastic consequences for a substantial body of economic theory and policy-making. In particular, it implies that the balance-of-payments problems suffered by Britain for much of the post-war period were due to over-expansionary fiscal policy alone. Since the Keynesian establishment in Britain has traditionally seen active fiscal policy as the correct way to maintain high employment, this approach to balanceof-payments analysis is most unsettling for them. Sir James Meade, one of the most distinguished of the British Keynesians, responded very critically to the ideas and wrote in protest to Lloyds Bank Review. A lively debate with an exchange of letters followed in the April 1983 issue.

Paradoxically, the new 'radical liberal' approach to the balance of payments proved to be very convenient to policy-makers during the Lawson boom. The excess demand generated by rapid monetary expansion was partly responsible for a sharp deterioration in the balance of payments in 1987 and 1988, but the fiscal position became extremely strong. In fact, a large budget surplus was recorded in 1988 and 1989. Mr Lawson was there- 
fore able to use the new approach to the balance of payments to give legitimacy to the large current account deficit. After Sir Terence Burns, the Government's Chief Economic Adviser, had articulated it as a justification for Britain's external deficit at the 1988 meeting of the International Monetary Fund and World Bank in Berlin, Mr Brittan of the Financial Times called the ideas 'the Burns doctrine' or 'the Lawson/Burns doctrine'. (In fact, the new approach was first suggested in some lectures given by Professor Max Corden at Chicago in 1976. But Corden's remarks were quite brief, and I believe that my 1982 article was the first extended treatment.)

The second period piece is a reprint of a paper I wrote jointly with my former colleague, Mr Paul Turnbull, at L. Messel \& Co., again in 1982. One puzzle at that time was that rapid growth of mortgage credit was not leading to a sharp rise in house prices. Mr Turnbull had done some work on mortgage lending while working at the Building Societies' Association in the 1970s, and had seen a similar pattern during previous episodes of buoyant mortgage lending. Meanwhile the clearing banks were lobbying the Government to remove informal restrictions on their mortgage lending. As part of this campaign Mr David Lomax of National Westminster Bank wrote an article in the February 1982 issue of the National Westminster Bank Quarterly Review which gave a very lucid description of how funds circulate in the housing market, including the statement, 'apart from mortgage lending used for new construction, for transactions costs, and for buying houses from the public sector, every penny of net additional credit for house purchase is taken out in equity from the housing market'. The idea of 'equity withdrawal' was born.

The paper I wrote with Mr Turnbull took the analysis further in three ways. It used the actual phrase 'equity withdrawal', I believe for the first time; it quantified the relative sizes of net mortgage credit and equity withdrawal; and it showed that there was nothing sinister about the phenomenon. On the face of it, the main conclusion was shocking, that - even when the mortgage market was subject to severe restrictions of various sorts in the late 1970 s - equity withdrawal exceeded investment in the housing stock. So more than half of net mortgage credit, highly tax-privileged because it was supposed to promote home ownership, was, in fact, not staying in the housing market at all. But we demonstrated through some familiar real-world transactions sequences, such as those following the death or retirement of homeowners, that equity would inevitably be withdrawn in the process of buying and selling houses. 'People quitting the housing market rightly regard the equity in their homes as their own property. They are entitled to do with it whatever they wish. It would be wholly wrong for the monetary authorities to impede them.'

The ideas in the paper were quickly taken up by the Bank of England, in its August 1982 Quarterly Review, without (I am afraid to say) any acknowl- 
edgement, and became staples in the academic analysis of savings and consumption in the rest of the 1980s. Sadly, however, the warning against single-digit interest rates in the final paragraph of the paper was not heeded by Mr Lawson in 1987 and 1988, with very harmful effects on the housing market and the economy. To quote the final paragraph: 'Credit is pouring into residential property at present [i.e., 1982]. The associated rapid growth of bank and building society deposits is threatening the Government's [broad money] targets. If interest rates come down quickly to 10 per cent or less, we can be confident that those targets would be unattainable and that an unsustainably vigorous upturn in housing market activity would develop.'

It seems a safe assumption that his advisers never brought the passage to Mr Lawson's attention. We have to ask him, as he prepares his memoirs, 'what advice were you receiving when you cut interest rates to under 8 per cent during the strongest credit explosion for 15 years?'. We might also ask, 'to which academic advisers were you listening most attentively and why?'. Did those advisers believe, in all seriousness, that annual monetary growth of 20 per cent would not have disastrous results both for the economy and the Thatcher Government?

\section{The Intelligent Radical's Approach to the Balance of Payments}

Reprinted from an article 'A new approach to the balance of payments' in the October 1982 issue of Lloyds Bank Review.

The balance of payments remains in the forefront of policy-makers' attention in many countries, particularly in the Third World. Discussion has been given new urgency by the prospect of default by sovereign borrowers, unable to repay substantial bank debts incurred in the 1960s and 1970s. As these practical problems have been subjected to considerable theoretical analysis, it may seem surprising that there is anything novel to say. However, the argument of this article is that valuable insights can be gained by a new method of formulating the balance of payments. The critical point of departure from previous work is to divide the economy into the public and private sectors, and to assess their contribution to a nation's overall balance of payments separately. By suggesting that a deficit incurred by the private sector results from freely-taken decisions by individuals and is not a problem for policy-makers, the spotlight is turned onto the deficit incurred by the public sector. A government's payments difficulties are interrelated with fiscal and debt management problems. Indeed, we shall claim that the central misunderstanding of traditional theories has been to regard the balanceof-payments problem as distinct from the problems of the budget deficit and 
government debt sales. The provocative conclusion reached here is that these supposedly independent problems are, in fact, one and the same.

This has drastic implications. The most important is that restrictions on international trade and financial flows are of little value in curing payments imbalance. They help only insofar as they improve tax revenues or increase domestic acquisition of public sector debt or, in other words, only because they affect fiscal and monetary variables. It would be more honest, and also less prone to cause distortions, to operate on these variables directly. There is an obvious message for the many Third World nations which, in response to balance-of-payments weakness, are now busy erecting tariff and nontariff barriers to trade. But the point is equally relevant for advanced industrial countries. In Britain, the Cambridge Economic Policy Group has warned that the balance of payments is damned beyond redemption by adverse longterm import trends, and that the only reliable method of countering these trends is import control. Although its prognosis has not so far proved correct, the Group's work has attracted much comment and seems to have encouraged the Labour Party to favour import restrictions. The ideas developed in this article suggest that, on the contrary, import restrictions would be almost useless as an antidote to international payments imbalance.

To help organize the argument we start with the familiar flow-of-funds identity. It states that the foreign sector's financial position is the counterpart to that of the public and private sectors combined:

Overseas sector's net acquisition of financial assets (NAFA) = public sector's NAFA + private sector's NAFA

When the overseas sector's net acquisition of financial assets is positive, a country is running a current account deficit. The conventional view is that a 'problem' exists if the deficit is unsustainably large and must be corrected by policy action. We may break down the total current account deficit into two parts:

\section{Current account deficit $=$ public sector deficit + private sector deficit}

This is not strictly accurate because the public or private sector might have a positive net acquisition of financial assets outweighed by a negative NAFA by the other, but it simplifies the discussion to assume that both sectors contribute - at least, in an arithmetical sense - to the current account deficit. Let us suppose initially that the current account deficit is attributable to the private sector. The private sector is running into debt with the rest of the world. 
Why does this matter? Within an economy it is an everyday event for companies and individuals to borrow from one another. They do so with advantage because they have different time preferences, different production opportunities or different cash flow patterns. Equally, it is possible for the set of private companies and individuals which comprise one economy to incur debt to the set of private companies and individuals which comprise another economy. Although every agent is acting independently, in the aggregate the private sector agents in one country have a current account deficit. Since the numerous borrowing decisions responsible for the deficit are taken freely, it is unclear why the government should be concerned or why policy needs to be amended. Perhaps, as Corden has remarked, 'One should...just assume for the purposes of discussing balance-of-payments issues that the private sector knows what it is doing, and what is good for it, as far as its spending and savings decisions are concerned.'

The objection might be raised that private sector agents may not be properly informed about the eventual results of particular financial transactions across frontiers. But the domestic and foreign agents concerned have to make their own judgement about the creditworthiness of the debt incurred. The task of ensuring that it can be serviced and repaid falls on them, not the government.

In the past, many countries have registered persistent private sector current account deficits with no detriment to their economies. The characteristic explanation is that they have been able to cover the deficits by capital inflows, normally attracted by a better rate of return than in the source country. The consequent higher level of capital accumulation has accelerated the growth of output, including exports, and enabled the debts to be repaid without difficulty. A classic illustration is provided by the USA in the 19th century. In the decade to 1878 its trade deficit averaged 0.8 per cent of net national product and the current account deficit, boosted by interest and dividend payments to foreign investors, was even larger. But in the early 20th century it began to earn substantial trade surpluses and became a capital exporter. ${ }^{2}$

Another possibility is that the domestic private sector may experience a temporary dip in income due, for example, to an adverse terms-of-trade shift. If consumption is related to 'permanent income', private individuals may wish to borrow from abroad in the expectation of better times ahead. If their expectations prove correct, and no one should be able to make forecasts better than themselves, they will be able to repay when the improvement materializes. ('Permanent income' is a concept advanced by Friedman in his 1957 study on A Theory of the Consumption Function. It abstracts from 'accidental' or 'chance' influences on income.) 
But some economists might protest that these arguments are based on too sharp a differentiation between public and private sector decision-taking. What happens if a private sector current account deficit emerges because companies and individuals misinterpret macroeconomic signals given by unsound official policy? When these signals are shown to have been wrong and the private sector cannot repay, should not the blame be placed on the government? And does not this carry the implication that policy-makers should be worried about a private sector current account deficit and take remedial measures if they think it excessive?

These questions raise some potentially awkward issues. The most troublesome example is where a central bank keeps interest rates 'too low', promoting heavy borrowing by the private sector and hence leading to a current account deficit. But it is necessary to remember that, unless they are prevented by official restrictions, private sector agents have discretion about the currency in which debts are denominated. Suppose that interest rates in, say, Brazil are 'too low', that bank credit, and so the money supply, is expanding quickly, and that the cruzeiro is under pressure. The probability of depreciation is known to private agents at home and abroad. Foreign lenders and Brazilian borrowers can intermediate in cruzeiros or, if they wish, in dollars or another recognized convertible currency. The foreigners - aware that depreciation of claims expressed in cruzeiro terms is likely - will take this into account when drawing up debt contracts. If they have little trust in the Brazilian bank because it is setting 'too low' interest rates, Brazilian individuals will be unable to borrow in cruzeiros from foreigners. It is a mistake to imagine that central banks can saddle residents of their country with huge foreign debts by tampering with interest rates in home currency terms. Of course, if Brazilians borrow in dollars they will have to pay a more appropriate interest rate and any exchange rate loss due to cruzeiro depreciation. ${ }^{3}$

The plain fact is that risk attaches - and, in a market economy, is understood to attach - to every credit transaction between private agents. Part of this risk stems from the difficulty of forecasting macroeconomic trends. This element in risk is found in borrowing and lending between residents of the same country. The main new dimension in borrowing and lending between residents of different countries is exchange rate variation. But, just as a central bank is not responsible for compensating agents in its own country when they have been upset by an unexpected interest rate change, so it should not be responsible for compensating agents at home or abroad because of an unexpected exchange rate change. The Federal Reserve need be no more involved if a company in Brazil defaults on a dollar loan than if a company in Massachusetts does so. By extension, why should a current account deficit between the private sectors of the USA and Brazil be of any 
more interest to it than a current account deficit between the private individuals of Massachusetts and California?

It is quite possible that, after international financial flows, private sector agents in both debtor and creditor countries find they have made mistakes. But, when one party to a credit transaction undertaken between nationals of one country defaults, there is no presumption that the government will automatically help the other party. It is therefore unclear why the government of one country should intervene if its citizens fail to honour their foreign debts. Apart from providing law courts to arbitrate on disputes, the state has no particular duty or obligation. To put the argument at its most polemical, there is no such thing as a balance-of-payments 'problem' between consenting adults.

The matter is quite different when we consider a current account deficit attributable to the government's behaviour. The deficit can be covered either by drawing down foreign currency reserves or by increasing external indebtedness. Reserve depletion is a finite process and must, at some stage, be reversed. There must also be some upper limit to the external indebtedness a government can tolerate, although the scope for debate about what that limit may be is considerable. Since both reserve depletion and foreign borrowing cannot continue for ever, a public sector current account deficit poses a genuine problem for policy-makers. They must sooner or later take action to solve it. But what action is needed?

The answer is contained by the identity:

Public sector current account deficit $=$ Public sector financial deficit sales of public sector debt to the domestic private sector (including money creation)

This makes the obvious statement that the public sector's contribution to a current account deficit is equal to the total increase in its financial liabilities minus that part of the total increase taken up by domestic savings. It is also clear that the external deficit can be reduced in two ways - by reducing the public sector financial deficit (which, from now on, we shall call 'the budget deficit' for brevity) or by increasing domestic sales of public sector debt. Any policy measure which does not affect the budget deficit or the domestic demands for government debt is futile as a response to balance-of-payments difficulties; any measure which does affect these two variables also changes the public sector's current account deficit. As we have already argued that the private sector's current account is not a relevant concern for policymakers, it follows that the solution to payments imbalance is to be sought 
only in fiscal or debt management policy. This is a strong assertion. If it is accepted, much previous analysis of the balance of payments is superseded.

There is no doubt that economists have not in the past seen balance-ofpayments problems exclusively in fiscal terms. In the next two sections we shall, therefore, consider the characteristic symptoms of payments imbalance in two recent periods, the fixed exchange rate regime before 1971 and the floating exchange rate regime subsequently, and relate these symptoms to fiscal and debt management policies.

In the Bretton Woods system of fixed exchange rates one key pressure-gauge for assessing balance-of-payments difficulties was the movement in foreign currency reserves. Central banks were expected to sell foreign currency and buy their own if the exchange rate was in trouble. By using their ammunition of accumulated dollars they could fight back against speculative attacks on their currency; if the ammunition was exhausted they had to admit defeat and accept the ultimate disgrace of devaluation. According to Johnson, writing during the period, the balance-of-payments concept relevant to 'policy properly defined and to the corresponding instruments of macroeconomic policy is the net inflow or outflow of international reserves' ${ }^{4}$ The theme can be dated back to his celebrated 1958 paper, 'Towards a general theory of the balance of payments', in which he stated that the 'balance of payments relevant to economic analysis' was the difference between residents' receipts from and payments to foreigners, with a deficit being 'financed by sales of domestic currency by residents or foreigners to the exchange authority in exchange for foreign currency'. ${ }^{5}$ Johnson clearly assumed the presence of an exchange authority, in the form of a central bank, acting as the principal intermediary between the citizens of one country and those of another. The pivotal role of such an authority was emphasized by the 'official settlements' definition of the balance of payments, which for several years in the late 1960 s and early 1970 s was deemed the best indicator of the need for policy adjustment. It corresponded roughly to the change in reserves, although it also included items which would alter the monetary authorities' international creditor/debtor position without affecting the reserves.

The need was to derive a theory which accounted for changes in the reserves. The monetary approach to the balance of payments was developed, notably by Johnson, in response to this need. It explained how the official settlements balance of payments was determined by the difference between the increase in the demand for money and domestic credit expansion. As such, it was 'a monetary phenomenon, representing a disequilibrium in the demand for money'. Johnson made strong claims for the monetary approach - for example, that it debunked much Keynesian analysis which had paid 
excessive attention to aggregate expenditure decisions as an influence on international payments.

But our formulation contains an alternative explanation of the official settlements balance. We make the assumption that the central bank has only two assets - claims on the domestic government and foreign currency reserves. In the 1950s and 1960s this would have been a realistic assumption in the overwhelming majority of countries. We also assume that the central bank is reluctant to expand its liabilities because additions to high-powered money may become the raw material for excessive growth of bank credit. In this case, if the government fails to borrow from the domestic private sector to cover its budget deficit, it must appeal to the central bank. The central bank can meet the demand only by selling foreign exchange - and any sales represent a deficit on official settlements. We seem to have turned Johnson's argument on its head. Far from being a monetary phenomenon, the official settlements balance of payments can be interpreted in fiscal terms. The solution to unfavourable official settlements is to be sought in reductions in the budget deficit or more aggressive attempts to sell government debt to domestic entities other than the central bank.

In fact, our conceptual somersault is only apparent. It is largely a semantic artefact and should not be taken too seriously. The budget deficit itself constitutes part of domestic credit expansion and may therefore be regarded as a monetary variable, while the demand for public sector debt is susceptible to monetary policy shifts, particularly changes in interest rates. There is no abrupt cleavage between monetary and fiscal instruments.

However, by stating the problem in fiscal terms some fresh insights have been generated. We have identified the government as the most likely culprit for an unsustainable imbalance on official settlements. The sequence of sterling crises in Britain illustrates the point clearly. Following recommendations from its Keynesian advisers, the government from time to time embarked on fiscal reflation which involved a deliberate increase in the budget deficit. After a relatively short period, often no more than a year or 18 months, there was a run on the reserves. The official reply was typically a 'package' of public expenditure cuts, taxation increases and higher interest rates. The balance of payments then convalesced and the reserve position improved. A rise in unemployment followed, prompting another bout of fiscal reflation, another sterling crisis and another 'package'. In Brittan's words, 'Chancellors behaved like simple Pavlovian dogs responding to two main stimuli: one was "a run on the reserves" and the other was "500 000 unemployed" - a figure which was later increased to above $600000 .{ }^{\prime 6}$ The stop-go cycle may be interpreted as reflecting the incompatibility of increased budget deficits with the maintenance of a fixed exchange rate against the dollar. This incompatibility was signalled by a fall in reserves. 
The Bretton Woods regime of fixed exchange rates was effectively terminated by the USA's decision to suspend the convertibility of the dollar into gold in August 1971. Since then the major currencies have for most of the time been floating against each other. This has changed the form of the typical balance-of-payments crisis. In the 1950s and 1960s, when the reserves were both the first and last line of defence, a run on the reserves necessitated early action on the budget deficit or interest rates. Today the option of devaluation is also available. The environment for deficit countries has become more permissive in another respect. Large international capital markets with the capacity to lend to governments for balance-of-payments financing have developed, with OPEC members being an important source of funds after the oil price rise of 1973/4. Instead of having to appeal to the International Monetary Fund, which imposed conditions to ensure a return to payments balance within a set timetable, deficit countries have been able to borrow from private commercial banks. As long as the banks have been persuaded that their loans will be repaid eventually, they have not been as rigorous as the IMF in expecting responsible macroeconomic policies.

The two new choices - devaluation and borrowing - have changed governments' perceptions about how they should meet payments difficulties. Particularly in the Third World, but also among many industrial countries, attitudes have become more lax. Budget deficits represent a much higher proportion of national income in nearly all countries. Are the frequency of devaluation and the scale of borrowing for balance-of-payments purposes related to these large budget deficits and, if so, in what ways?

We stated earlier that the public sector current account deficit was equal to the budget deficit minus domestic debt sales. At first sight, devaluation is not much help in curing the deficit because it has no obvious repercussions on either the budgetary position or debt sales. However, this is too superficial a view. There are indirect relationships, working through the balance sheets of the central bank and the domestic commercial banks, between devaluation and a government's ability to finance its deficit internally.

Devaluation is usually followed by a rise in the price level. The higher price level is accompanied by an increased demand for both the monetary base and money (i.e. an increased willingness to hold the liabilities of the central bank and the commercial banks). As a result the banking system can expand its assets without disturbing monetary equilibrium. The central bank, as banker to the government, is always under an obligation to take on more public sector debt. In an economy free from official regulations, the commercial banks might refuse to lend to government if they thought the loans would be unprofitable. But in most Third World countries the banks are either nationalized or subject to some degree of official arm-twisting. They have to accept new public sector debt in their balance sheets. 
In other words, devaluation enables a government to increase its domestic debt sales. The high price level associated with it causes the private sector to wish to hold more notes and coin, and more bank deposits. By holding more monetary assets economic agents are - through a circuitous route - purchasing more government debt. Notes and coin are claims on the central bank, but the central bank matches them by claims on government; and deposits are liabilities of banks, but banks match them by investing in government paper.

Indeed, it is an open question whether devaluation should be regarded as a method of promoting domestic debt sales or as a way of levying the inflation tax. An econometric analysis of Italy's exchange rate movements in the 1970s concluded that: "The monetary financing of over one-third of the government's deficit effectively implied that...nine-tenths of the increase in the total monetary base was accounted for by the Treasury, causing an expansion in high-powered money well in excess of that which would have been consistent with a reasonable stability in the value of the lira.' Its author judged that 'the sharp increase in the monetary base plus inflation meant that the public paid a growing part of taxes in the form of the inflation tax on money balances. Indeed, according to some rough estimates I have made in the three years $1972-75$, the yield from this tax turned out to be almost equal to that from income tax."7

But Italy is only a mild example of the problems which can arise. In many Third World countries, particularly in Latin America, devaluation is almost synonymous with inflation. Consequently, it may seem preferable for a government with a large budget deficit to borrow abroad. No hard and fast criteria for deciding whether a government's external debt is excessive have been agreed. Clearly, one requirement for the sustainability of a foreign borrowing programme is that the citizens are willing to pay sufficient taxes to cover interest charges and maturing capital payments. But the question of the government's ability to repay principal is more awkward and problematic. There is no obvious rule which says whether a particular ratio of public sector foreign debt to taxable capacity (usually proxied by national income) is too high. Sovereign risk is a very controversial subject among bankers. In principle, a government could be running a continuous current account deficit as long as the resulting growth of its foreign debt and servicing costs is no faster than the growth of its national income. The situation becomes unsustainable only when this condition is violated. In that case the government must sooner or later take measures to reduce its foreign borrowing. If no measures are taken, the government will finally be unable to pay interest and will have to seek rescheduling of its debt.

Balance-of-payments crises since 1971 have, therefore, been rather different dramas from those in the 1950s and 1960s. Whereas the main actors in 
the play used to be the government and the IMF, and the most absorbing item of stage scenery a change in the reserves, today international bankers have been added to the cast, and devaluation and debt service ratios to the props. But the responsibility for balance-of-payment problems still rests with governments and their budget deficits.

Direct restrictions imposed for balance-of-payments reasons are of two main kinds - import controls and exchange controls. Are either of any value in solving a public sector current account deficit?

Import controls on private sector transactions are by themselves of little use. A public sector current account deficit is equal to the difference between two numbers - the public sector financial deficit and sales of public sector debt to the domestic private sector. Import controls can reduce it only insofar as they affect these variables. Tariffs yield revenue to the government and therefore lower the budget deficit. But otherwise there are no obvious linkages at work. ${ }^{8}$ Some favourite Third World responses to payments imbalance, such as quotas or placing luxuries on a list of prohibited imports, are futile, as public sector finances are unaffected. Aside from the boost to revenue from tariffs, import controls are pointless as an instrument for reducing the public sector's current account deficit. Nothing more needs to be said.

Exchange controls are more interesting. The most characteristic exchange control is a requirement that the private citizens of a country keep no foreign exchange in their own names and transfer any holdings to the central bank in return for domestic currency. Two observations may be made here.

First, exchange control may be viewed as serving the same function as devaluation. It increases the private sector's demand for government debt. When private sector agents are legally obliged to surrender foreign exchange to the central bank, they receive central bank liabilities in return (i.e. highpowered money in the form of notes or balances at the central bank). More frankly, they are forced to invest in the central bank. The central bank, as banker to the government, in turn invests in public sector debt. The private sector has indirectly financed the public sector deficit and may, to that extent, have reduced the public current account imbalance. However, this arrangement, which in any case is rather distasteful since it rests on compulsion, is unstable. If the private sector's holdings of high-powered money are above desired levels because of exchange controls, it attempts to reduce them. It can do so most obviously by using the excess high-powered money as the base for inflationary credit expansion. The monetary authorities may hinder this by introducing credit restrictions on private banks. This reaction is extremely common and helps to explain why so many central banks throughout the world are to be seen enforcing exchange controls and admin- 
istrative credit restrictions simultaneously. The panoply of controls may be interpreted as the result of competition between the government and the private sector for foreign exchange and, at a deeper level, for resources of any kind.

Secondly, exchange control resembles inflation in that it is a form of taxation. Without exchange control, private sector agents would not convert their foreign currency into domestic. It follows that, after compulsory conversion, there is excess supply of the domestic currency, and its marketclearing price (in terms of foreign currency) is beneath the official price. The difference between the market-clearing and official exchange rates is an incentive for the creation of black markets. It is also a measure of the government's exchange control tax. As an instrument of taxation, exchange control enables governments to finance their foreign purchases at a lower price in domestic currency terms than would otherwise be the case. In this sense, it reduces the public sector financial deficit. The success of exchange control as a tax is, however, hazardous to estimate in advance, since the government cannot know what proportion of the private sector's foreign exchange may seep out through the black market. The existence of black markets is another symptom of competition between the government and the private sector for resources; it is the result of government failure to pay for its expenditure by more visible and honest forms of taxation.

We have to concede that exchange controls, if they are effective, may cut the public sector's current account deficit. But they do so through means taxation and increasing domestic demand for public sector debt - which have always been available to governments in more transparent forms. Exchange controls have no merits compared to the conventional techniques, and they suffer from several obvious disadvantages. Not least among these disadvantages is the contempt for government aroused by the arbitrary character of the exchange control tax.

In summary, the messages of the new approach to the balance of payments are that only foreign debts incurred by the public sector constitute a balanceof-payments problem, and that the only solution is the pursuit of more appropriate fiscal and debt management policies. A further implication is that a country whose government has adopted responsible budgetary policies cannot have external payments difficulties. The new approach provides reinforcement for the 'old-time religion' of sound finance and balanced budgets.

But the contrast between the white of private sector deficits and the black of public sector deficits should not be exaggerated. There are grey areas. Two deserve particular mention, as they are of some topical interest. The first is where public sector agencies borrow abroad to finance capital projects. If these are expected to generate a rate of return above the cost of funds, no 
extra burden is imposed on the taxpayer and no strong case for differentiating this form of public foreign borrowing from private can be argued.

The second arises when heavy overseas borrowing is conducted by private banks, which on-lend to companies and individuals. This should be distinguished from credit flowing directly from foreign entities to the domestic private sector because bank deposits are in most countries guaranteed by the central bank, which is a public sector body. If the companies and individuals who ultimately receive the funds are unable to repay the banks, the central bank has to interfere to protect depositors' interests. Central bank interference is necessarily a matter of public policy. This unintentional involvement of government in private sector financial transactions has occurred in some Latin American countries. A notable example is Chile which, in 1980 and 1981, simultaneously had a budget surplus and a big current account deficit stemming from heavy private sector borrowing abroad. In 1982, many of the private sector loans went wrong and central bank refinancing of the bad debts contributed to a sizeable budget deficit. Despite cautious fiscal policies, excessive borrowing by the private sector eventually undermined the country's credit rating.

These two special cases are only minor qualifications to the central theme. They in no sense invalidate the emphasis on fiscal policy as the key to the balance-of-payments 'problem'. Indeed, if bankers want to avoid some of the sovereign debt difficulties they are now facing, they should in future focus on fiscal variables to assess a government's ability to repay. The abundance of a country's natural resources is of limited value unless they can be translated into tax revenue. Assertions such as 'Mexico has oil' and 'Argentina's agricultural potential is so great its finances can always be turned round' have been heard to justify the large loans extended to these two nations over the last decade. But Mexico's oil and Argentina's agricultural potential are not by themselves any help to foreign bankers holding claims on their governments. Bankers need dollars, not oil or beef. The only way, apart from borrowing, that the Mexican or Argentine governments can obtain dollars is by purchasing them with local currency; and the only way, apart from printing, that these governments can acquire surplus local currency is by having an excess of tax receipts over expenditure. If there is no prospect of a Third World government reorganizing its public sector finances after a foreign borrowing programme, it is unwise for banks to participate in that programme while it is under way.

Although reschedulings of Third World debt are the most topical application of the new approach to the balance of payments, it is also relevant to recent policy debates in the developed countries. It shows, for example, that the Cambridge Economic Policy Group's advocacy of import controls as an answer to future payments imbalance in Britain is misguided and unsound. 
There is a balance-of-payments problem only if the government has a financial deficit which it cannot cover by domestic debt sales. Paradoxically, a reliable method of creating such a problem would be fiscal reflation of the kind proposed in the 'alternative economic strategy' and supported by the Cambridge Economic Policy Group. A further irony might be mentioned. There is a resemblance between our approach to the balance of payments and the New Cambridge School theory of the mid-1970s. The gravamen of this theory, also developed by the Cambridge Economic Policy Group, was that the government's budget deficit - and only the government's budget deficit - was responsible for payments imbalance. Cambridge economists seem not to have recognized that this conclusion is inconsistent with their subsequent enthusiasm for import controls. Tariffs on finished manufactures would mitigate the problem to the extent that they boosted tax revenue, but otherwise they would be quite pointless.

If the British Government wants to avoid external constraints on economic policy, it should ensure that budgetary policy remains responsible. As long as the public sector borrowing requirement is a low and declining proportion of national income, Britain will not suffer from a balance-ofpayments problem.

\section{Notes}

1. W. M. Corden, Inflation, Exchange Rates and the World Economy, Oxford 1977, p. 45. The aim of the present article can be regarded as giving Corden's insight further elaboration.

2. G. E. Wood and D. R. Mudd, 'The recent US trade deficit' Federal Reserve Bank of St Louis Review, April 1978, p. 3.

3. I have clarified my thinking on this point after correspondence with Professor W. M. Corden. There is a special difficulty if the central bank, a public sector entity, is borrowing abroad at high interest rates and then extending cheap credit to the domestic private sector.

4. See H. G. Johnson, 'The monetary theory of balance-of-payments policies', pp. 262-84, in J. A. Frenkel and H. G. Johnson (eds), The Monetary Approach to the Balance of Payments, London 1976. The quotation is from p. 262.

5. H. G. Johnson, 'Towards a general theory of the balance of payments', pp. 153-68, in International Trade and Economic Growth (London: Allen \& Unwin 1958), reprinted on pp. 237-55 of R. N. Cooper (ed), International Finance (Harmondsworth: Penguin 1969). The quotations are from p. 239 of Cooper's collection.

6. S. Brittan, Steering the Economy (Harmondsworth: Penguin 1971). The quotation is from p. 455.

7. R. Masera, 'The interaction between money, the exchange rate and prices: the Italian experience in the 1970s', pp. 233-47, in A. S. Courakis (ed.), Inflation, Depression and Economic Policy in the West, London 1981. The quotations are from p. 244.

8. In countries where collection costs of domestic taxes are high, 'tariffs and export taxes may form part of a first-best tax package'. (W. M. Corden, Trade Policy and Economic Welfare, Oxford 1974, p. 66.) In fact, there are many developing countries where tariffs are introduced or raised explicitly for revenue-raising rather than protectionist purposes. 


\section{Introducing the Concept of 'Equity Withdrawal'}

From a paper of 4 June 1982 'The coming boom in housing credit' from the stockbroking firm, L. Messel \& Co., written by Tim Congdon and Paul Turnbull.

Several signs of a very large increase in finance for house purchase have appeared recently. The building societies promised a record $£ 1,491$ million to mortgage applicants in March and $£ 1,416$ million in April. (The previous high was $£ 1,210$ million in March 1981.) Meanwhile the April London clearing banks' statement referred to 'a further sharp rise in house mortgage finance'. Mortgage lending by banks and building societies combined is likely to be about 40 per cent higher in the second quarter of 1982 than a year earlier, and roughly double that in the second quarter of 1980 .

The boom in housing credit has created problems of both analysis and policy. The analytical problem is to reconcile the volume of funds now pouring into the housing market with the relative stability of house prices. It seems that a significant, and perhaps rising, proportion of loans designated for 'house purchase' are actually being used for other purposes. We will argue strongly that there is nothing sinister in this and it would be quite wrong for the Bank of England to stop it. The policy problem is that there are domestic constraints on further large interest rate reductions. Of course, if the economy can recover with the base rates of 12 per cent or 13 per cent which currently prevail, that is not by itself a cause for anxiety. But investors' hopes of short-term interest rates of 10 per cent or less in 1982 will be disappointed. Before we draw our conclusions for interest rates we need to identify the influences on the boom in housing credit and see how they are likely to unfold in coming quarters.

The main cause of the housing credit boom is the liberalization of the financial system. In 1981 the banks, already freed from 'corset' restrictions, were allowed to ignore the qualitative guidelines on personal sector lending originally imposed by the Bank of England in December 1973. (No formal announcement of the change was made.) They sought new business in the home mortgage market, putting the building societies under severe competitive pressure. The societies have retaliated by actively marketing their mortgage facilities.

Recent developments are in sharp contrast to the post-war norm. In the 1960 s and 1970 s there was a continuous excess demand for housing finance. The most well-known symptom was the mortgage queue, taken for granted as natural and inevitable by all home-buyers. The explanation for excess demand was that building societies and banks were unable to lend as much 
as they wished because of a variety of official restrictions. The societies, which are mutual associations and do not maximize profits anyway, could lend all the deposits they received. But for most of the 1970 s the Government wanted to prevent a house price explosion similar to that in 1971-73. Restrictions on mortgage advances, laid down by a government-backed body called the Joint Advisory Committee, were in operation on several occasions. The societies, with the scope of their activities necessarily limited in this way, discriminated in favour of small and first-time borrowers. For example, they charged a differential (i.e., higher) rate for mortgages above a certain size.

The position of the banks was even more straightforward. In December 1973, following the notorious excesses of the Barber boom, the Bank of England issued a notice which said that, 'Banks and finance houses are asked to reinforce strongly their restraints on lending to persons generally, to property companies and for purely financial transactions.' This was taken to indicate that home mortgage lending was 'low priority' and would be disapproved by the Bank of England. The banks therefore undertook virtually none in the 1970s, except on behalf of their own staff.

The relaxation of regulations in 1981 changed the situation radically. The banks entered the mortgage market in a big way - and, for reasons which remain unexplained, the Bank of England did nothing to stop them. In the quarter to November 1980 they lent $£ 124$ million for house purchase; in the quarter to November 1981 they lent $£ 920$ million. By the end of the year the building societies were in the unusual position of not being able to lend out all the money they had available. Several of them responded by ending the differential rate structures so that they could compete more effectively at the top end of the market. There was also a weakening of the cartel arrangements on deposit inflows. In theory, the share rate (i.e. for deposits withdrawable on demand) is agreed by the Building Societies' Association and applies to all societies. But, in practice, societies have in recent years offered different rates to savers on term shares. Not only has new competition between banks and building societies emerged, but also competition between the societies themselves has developed in an unexpected way.

The result of the liberalization moves is that excess demand for housing finance is now being eliminated. Anyone who wants to buy a residential property can find the funds - if he is prepared to pay the price. The volume of money entering the housing market has therefore risen massively. This is an undoubted improvement in the structure of the financial system. An efficient financial system allocates funds (and, implicitly, real resources) by price; it does not ration them by queues. The latest changes should be seen as a further extension of the Competition and Credit Control reforms which 
began in 1971 and have done so much to strengthen competition between financial intermediaries.

Largely because of the liberalization of housing credit the total amount of house purchase advances by all institutions was nearly 30 per cent higher in 1981 than in 1980 . The quarterly pattern of the increase is shown in Table 10.1. But there seems to have been remarkably little effect on the housing market. Indeed, the Building Societies' Association index of all house prices was 4.4 per cent lower in January 1982 than a year earlier. How can the surge of new credit and the static property market be reconciled?

Table 10.1 The quarterly pattern of borrowing for house purchase in 1981

\begin{tabular}{|c|c|c|c|c|c|c|c|}
\hline & & \multicolumn{5}{|c|}{ Borrowing (in fmillion) for house purchase from } & \multirow{2}{*}{$\begin{array}{c}\% \text { rise } \\
\text { on } \\
\text { year } \\
\text { earlier }\end{array}$} \\
\hline & & $\begin{array}{l}\text { Building } \\
\text { societies }\end{array}$ & Banks & $\begin{array}{c}\text { Local } \\
\text { authorities }\end{array}$ & Others & Total & \\
\hline 1980 & 4th qtr & 1708 & 130 & 71 & 229 & 2138 & +28.6 \\
\hline \multirow[t]{4}{*}{1981} & $1 \mathrm{st}$ & 1561 & 210 & 11 & 201 & 1983 & +23.7 \\
\hline & 2nd & 1808 & 390 & 25 & 207 & 2430 & +41.9 \\
\hline & $3 \mathrm{rd}$ & 1560 & 730 & 65 & 208 & 2563 & +32.9 \\
\hline & 4th & 1270 & 870 & 149 & 153 & 2442 & +14.2 \\
\hline
\end{tabular}

Source: Financial Statistics, April 1982

The key to the reconciliation must be that much of the money was destined for purposes other than house purchase. A very clear statement of how funds circulate in the housing market was given by David Lomax in an article in the February 1982 National Westminster Bank Quarterly Review:

The essential point is that apart from mortgage lending used for new construction (new houses or extensions), for transactions costs, and for buying houses from the public sector (council house sales), every penny of net additional credit for house purchase is taken out in equity from the housing market. This is an arithmetic identity, stemming from the fact that if one is trading a given stock of assets among the population, then by definition if somebody increases his or her net debt to buy into the existing stock, somebody else must be taking that amount out of the system. One does not know at which point in the chain the equity is taken out of the housing market, but the amount taken out must be equal to the total net additional credit, subject to the adjustments mentioned above. 


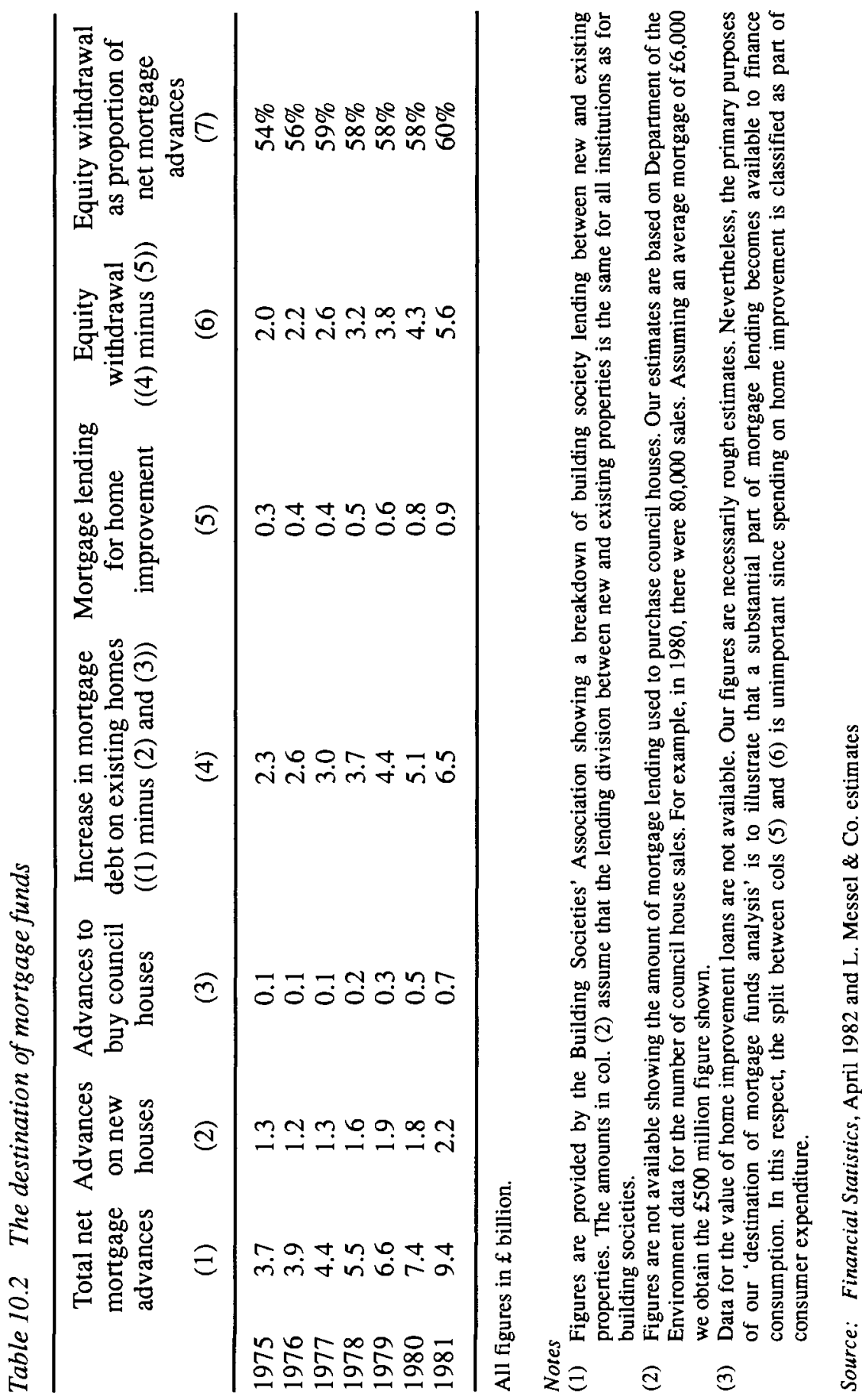


The items in the 'arithmetic identity' mentioned by Lomax can be estimated and some conjectures made about the size of equity withdrawn from the housing market. The estimates are presented in Table 10.2.

As can be seen, equity withdrawn has in recent years continuously been more than half of net mortgage advances. In other words, most of the mortgage credit extended by building societies and banks does not increase the housing stock owned by persons - even though the funds are categorized as being for 'house purchase'. Moreover, a big rise in net mortgage advances may not be translated into higher house prices if there is a change in the level of equity withdrawn. In 1981 the proportion of equity withdrawn to net advances seems to have increased, although not very dramatically. This, combined with the absorption of significant funds by council house purchases, prevented the quite strong growth in mortgage lending having much impact on house prices. (The method of calculating the split between increase in equity and equity withdrawn is explained in the notes to Table 10.2.)

It may seem odd that so much mortgage money does not end up - or, at least, does not appear to end up - in residential property. How is this at first sight very curious phenomenon to be explained? What are the main forms of equity withdrawal? Four should be mentioned:

1. Departures from the owner-occupied market.

2. Trading down.

3. Sales of formerly rented houses by private landlords.

4. Equity release in house transfer.

Each may be analysed in more detail.

Departures from the owner-occupied market These arise most commonly on the death of an owner-occupier when the sales proceeds are distributed to next of kin and other beneficiaries in the will. The money received by the legatees may be spent on consumption or invested in other assets rather than retained in the housing market.

Trading down There are two principal examples here. First, on retirement or in old age households often move into smaller and less expensive properties. Secondly, in mid-career many individuals may unfortunately suffer a major deterioration in their economic prospects because of redundancy, bankruptcy and so on. Again they are obliged to live in more modest accommodation.

Sales of formerly rented houses by private landlords These have proceeded steadily over the years, with occasional encouragement (such as the 1974 
Rent Act) from legislation against the private landlord. The remaining stock of privately rented accommodation is now down to almost 12 per cent of all households.

Equity release in house transfer The mechanics of equity-releasing transactions are quite straightforward. Suppose someone has owned a property for five years which he bought for $£ 10,000$ with a mortgage of $£ 8,000$. The house is now worth $£ 20,000$ and the mortgage has been reduced to $£ 7,000$ by repayments. He receives a promotion and is able to buy another house worth $£ 30,000$ with a mortgage of $£ 24,000$. Although he has moved into a larger property, he has withdrawn equity because the increase in borrowing exceeds the increase in the value of his home. The opportunity is created because borrowing can be swapped for equity. The equity released becomes available for consumption or investment in other assets. It should be emphasized that building societies have traditionally hindered equity-releasing transactions by existing borrowers because it reduced the amounts they could lend to first-time buyers.

Why should any of these four types of equity withdrawal have been greater in 1981 than in previous years? Both departures from the owner-occupied market and sales of rented accommodation should be stable from year to year, the first being determined by demographic trends and the second by institutional factors. The scope for variation in equity withdrawal arises in trading down and equity release in house transfer. There is, in fact, likely to have been a substantial increase in both categories in 1981. Because of the recession, which involved a very high level of redundancies and early retirements, trading down must have been more frequent than ever before. Equity release in house transfer may also have been on a much increased scale. In the much more competitive environment in housing finance last year, the building societies were probably less concerned about having enough money for first-time buyers and less fussy about whom they lent to. The banks also may have taken a relaxed attitude about the ultimate destination of their loans.

The potential for equity release in house transfer depends on the gap between mortgage debt and the current market value of residential property. After the two house price booms of 1971-73 and 1978-79 this gap is now very large. Some relevant figures are given in Table 10.3. The personal sector's net equity in the housing stock amounted to nearly $£ 250$ billion at the end of 1980. In principle, the whole of it is available for consumption or reallocation into different assets. In practice, of course, if everyone tried to sell their houses and there was not simultaneously a flood of credit to enable them to buy others, house prices would collapse. However, there is obvious 
Table 10.3 The value of the personal sector's equity in the housing stock

\begin{tabular}{|c|c|c|c|c|c|c|}
\hline & \multicolumn{6}{|c|}{ Holdings (in fmillion) at 31 st December } \\
\hline & 1975 & 1976 & 1977 & 1978 & 1979 & 1980 \\
\hline Value of dwellings & 137525 & 152960 & 167794 & 218352 & 270949 & 300707 \\
\hline \multicolumn{7}{|l|}{$\begin{array}{l}\text { Liabilities incurred } \\
\text { in house purchase }\end{array}$} \\
\hline $\begin{array}{l}\text { to building societies } \\
\text { to banks } \\
\text { to insurance companies } \\
\text { to public sector } \\
\text { to TSBs }\end{array}$ & $\begin{array}{r}18882 \\
1310 \\
1520 \\
3254 \\
\end{array}$ & $\begin{array}{r}22500 \\
1390 \\
1563 \\
3381 \\
-\end{array}$ & $\begin{array}{r}26600 \\
1510 \\
1577 \\
3403 \\
\\
10\end{array}$ & $\begin{array}{r}31712 \\
1780 \\
1623 \\
3377 \\
15\end{array}$ & $\begin{array}{r}36981 \\
2370 \\
1847 \\
3744 \\
22\end{array}$ & $\begin{array}{r}42696 \\
2860 \\
2107 \\
4446 \\
115\end{array}$ \\
\hline $\begin{array}{l}\text { Total liabilities } \\
\text { for house purchase }\end{array}$ & 24966 & 28834 & 33100 & 38507 & 44964 & 52224 \\
\hline $\begin{array}{l}\text { Equity in housing stock } \\
\text { (i.e. value of dwellings } \\
\text { minus liabilities incurred) }\end{array}$ & 112559 & 124126 & 134694 & 179845 & 225985 & 248483 \\
\hline Personal disposable income & 78448 & 89276 & 103176 & 121808 & 150676 & 168560 \\
\hline $\begin{array}{l}\text { Ratio of equity in } \\
\text { housing stock to personal } \\
\text { disposable income }\end{array}$ & 1.43 & 1.39 & 1.31 & 1.48 & 1.50 & 1.47 \\
\hline
\end{tabular}

Source: Financial Statistics, February 1982

scope for the personal sector in certain years to borrow more than the increase in its housing investment, while retaining massive net equity. Indeed, residential property represents ideal security for consumer credit from banks, finance houses and retailers. Loans granted for 'house purchase' and then used for another end are indistinguishable, in economic terms, from loans for consumer credit made against the security of residential property.

There is no doubt that in 1981 the banks were allowed much more freedom to make consumption loans to individuals than they had been in the past. The absence of a formal relaxation of the official qualitative guidelines imposed in December 1973 does not invalidate the point. It is therefore more than a little curious that on 20 January 1982 the Bank of England issued a statement that it was 'concerned to ensure that lending on mortgage for house purchase should in fact be applied to the purchase or improvement of residential property and not to the realization of capital profits on their houses by the borrowers'. Ordinary consumer loans, which the Bank certainly 
now permits, are almost identical in their effects to equity release in house transfer, about which it has expressed its disapproval. We shall say more on this subject in a later section.

In summary, there is no puzzle about a 30 per cent jump in housing credit coexisting in 1981 with little change in house prices. Our estimate in Table 10.2 is that because of more trading down and equity release on house transfer a smaller proportion of net mortgage advances ended up in the housing market than in 1980 . With money being absorbed to buy council houses and to eliminate part of the unsold stock of new private sector houses, little movement occurred in house prices despite much increased flows through the main house mortgage institutions. The housing market has not defied the laws of supply and demand.

But what will happen in 1982? The indications are that in the second quarter net mortgage advances by all institutions might amount to $£ 3.45$ billion. Over the year as a whole a figure of $£ 13$ billion is quite feasible. Interesting comparisons can be made with previous experience.

In the 1971-73 boom equity withdrawal was an unusually high proportion of funds entering the housing market. Between 1970 and 1972 net mortgage advances by building societies more than doubled from $£ 1,088$ million to $£ 2,215$ million, while the amount channelled towards purchasing new dwellings went up less than 70 per cent from $£ 510$ million to $£ 862$ million. The discrepancy implies that much of the leap in building society lending found its way into consumption or other investment. If our estimates are correct, the rise in net mortgage advances between 1981 and 1982 will be less than in the early 1970s, but still spectacular. We would therefore expect equity withdrawal again to absorb an increasing proportion of mortgage funds. As a working hypothesis, we suggest 62 per cent, compared with 60 per cent in 1981. Another outlet is mortgage money to buy council houses. Sales of council houses are running at a higher level than the Government or the local authorities expected. Newspaper reports suggest that the total may reach 160,000 in 1982 , compared with 104,000 in 1981. Assuming the average mortgage is about $£ 6,000$, we obtain an estimate of nearly $£ 1$ billion for advances to buy council houses in 1982. Some mortgage lending is for home improvement and, in effect, adds to equity in the property market. As no precise statistics from the Building Societies' Association are available of its scale, the figures in Table 10.2 are our own estimates. A sharp rise seems likely in 1982 because both building societies and banks are marketing facilities for this fringe form of finance quite hard. We suggest $£ 1.1$ billion in 1982 compared to $\mathrm{f} 0.9$ billion in 1981. 
We are now in a position to prepare an estimate for mortgage funds to be directed towards the acquisition of new houses in 1982. The calculation is given below:

\begin{tabular}{llc} 
& & fbn \\
less & Total net mortgage advances in 1982 & 13.0 \\
& (Increase in housing market equity & -8.0 \\
less & Purchases of council houses & 5.0 ) \\
less & Mortgage lending for home improvement & -1.0 \\
& Mortgage funds to purchase new houses & $\underline{-1.1}$ \\
\cline { 2 - 2 } &
\end{tabular}

The $£ 2.9$ billion 1982 total is a striking improvement on the $£ 2.2$ billion figure in 1981. Of course, it is not the same as all personal sector investment in dwellings because most homebuyers also put in part of their own savings. In 1980, for example, the average mortgage advance on new properties by building societies was $£ 14,696$, compared to an average new house price of $£ 26,131$. Typically, therefore, mortgage funds to purchase new houses are equivalent to between 55 and $60 \%$ of private sector investment in dwellings.

Table 10.4 Private sector investment in dwellings: the record in recent years and a projection for 1982

\begin{tabular}{lccc}
\hline & $\begin{array}{c}\text { Advances } \\
\text { on new } \\
\text { houses } \\
\text { (fbillion, current } \\
\text { prices) }\end{array}$ & $\begin{array}{c}\text { Proportion of } \\
\text { advances to } \\
\text { total investment } \\
(\%)\end{array}$ & $\begin{array}{c}\text { Private sector } \\
\text { investment in } \\
\text { dwellings } \\
\text { (fbillion, current } \\
\text { prices) }\end{array}$ \\
\hline 1975 & 1.3 & 59 & 2.2 \\
1976 & 1.2 & 50 & 2.4 \\
1977 & 1.3 & 52 & 2.5 \\
1978 & 1.6 & 50 & 3.2 \\
1979 & 1.9 & 58 & 3.3 \\
1980 & 1.8 & 51 & 3.5 \\
1981 first 3 qts & 1.7 & 68 & 2.5 \\
1981 estimate & 2.2 & 60 & 3.7 \\
1982 projection & 2.9 & 60 & 4.8 \\
\hline
\end{tabular}

Source: L. Messel \& Co. estimates and Monthly Digest of Statistics 
Using this ratio, we give in Table 10.4 an estimate of private housebuilding investment in 1982 and compare it to recent years. There is a big jump from $£ 3.7$ billion to $£ 4.8$ billion, equivalent to almost 30 per cent - between 1981 and 1982. As substantial spare capacity persists in the construction industry and no serious land shortages are to be found, this increase will feed through mainly into housing starts rather than house prices. The evidence available so far in 1982 supports this interpretation. In the first quarter the number of private sector housing starts was 38,700 (seasonally adjusted), compared to an average of 29,100 per quarter in 1981. House prices have edged up, but not significantly. According to Building Societies' Association statistics, the average price of a new house was $2.9 \%$ higher in March 1982 than in December 1981. Since then there may have been some further movement. The Financial Times (25 May) reported the most recent quarterly survey of the Royal Institution of Chartered Surveyors (RICS), many of whose members are estate agents. The RICS was said to be looking for a change in market sentiment. According to Mr John Thomas, RICS spokesman on the housing market, the figures for April and May 'will probably illustrate that the harassed sellers of 1981 are gradually being replaced by those eager to buy while prices are still reasonably competitive'. An increase in house prices of between 5 per cent and 10 per cent between the end of 1981 and the end of 1982 seems the most likely outcome.

The projections made here rest on many assumptions, all of which can be questioned. Perhaps the most important is that we are not expecting any major change in interest rates from their present levels. A drop in base rates to 12 per cent seems likely in the next few weeks, but interest rate declines thereafter would undermine even further the Government's chances of staying within its sterling M3 and PSL2 targets. But what would happen if the Government placed more emphasis on the recovery and allowed interest rates to drop to, say, 10 per cent at some stage in the third quarter?

Before the liberalization of the housing market it was easy to work out the relationship between interest rates and net mortgage advances. The building society share rate lagged other interest rates and the changed differential between it and these other rates affected the volume of inflows into the societies. All the money taken by the societies could be lent. Today circumstances are different because banks are in the market, and they can expand their loans and deposits by a stroke of the pen. The key question has become 'how responsive is the demand for bank mortgage finance to interest rates?'. Obviously, we cannot tell because our experience of a free housing finance market is so limited.

But we can make some rough estimates. Before liberalization, a 1 per cent change in the differential between building society share rate and the banks' 
deposit rate would induce new inflows of about $£ 75$ million a month. A cut in rates would mean, however, that less interest was paid by existing mortgage borrowers - leaving about $£ 50$ million a month extra available for mortgages. The underlying demand for finance is bigger than that which passed through building societies. We would suggest that a 1 per cent drop in interest rates adds $£ 70$ million to $£ 80$ million a month to the demand for mortgage finance, equivalent to $£ 850$ million to $£ 950$ million at an annual rate.

If interest rates fell to 10 per cent in the third quarter and stayed there, we would have about $£ 1^{3 /} / 4$ billion extra finance compared to our base estimate. In the year from mid-1982 to mid-1983, this would suggest net mortgage advances of about $£ 15^{1 / 4}$ billion. On plausible assumptions about equity withdrawal similar to those above, finance available for buying new houses would amount to $£ 3.5$ billion, significantly more than the $£ 2.9$ billion projected for calendar 1982.

In January the Bank of England admonished the banks that mortgage lending should be for the purchase or improvement of residential property - and for no other purpose. Moreover, such lending should not allow 'the realization of capital profits on their houses by the borrowers'.

Our analysis shows that this warning is misconceived. For many years more than half of mortgage lending by the building societies has not actually been for 'the purchase or improvement of residential property'. The proportion of net mortgage advances used for equity withdrawal was consistently between 55 per cent and 60 per cent during the 1970s. Banks' entry into the housing market may have been followed by a small increase in the proportion in 1981, but the change was very marginal. The siphoning-off of mortgage funds into consumption or other investment was not caused by anything sinister or imprudent. It was the consequence of building society managers doing their job in the normal way. There are entrants and quits in the housing market, just as there are entrants and quits in the labour market. People quitting the housing market rightly regard the equity in their homes as their own property. They are entitled to do with it whatever they wish. It would be wholly wrong for the monetary authorities to impede them. For example, an elderly couple nearing retirement may decide to sell their home, which they own outright, for $£ 50,000$ and use the proceeds to generate income to supplement their pension. The purchase may be granted a 90 per cent mortgage by a bank. The personal sector's equity in the house has been cut from $£ 50,000$ to $£ 5,000$. But who could object to this sequence of transactions? Everyone concerned - the elderly couple, the homebuyer and the bank - is happy with its results. Why stop it? 
Some Bank of England officials might say that they have no objection to individuals taking out equity when they are trading down, as they clearly are in the elderly couple case. There is misbehaviour, so they might claim, only when equity is released by trading up, where borrowing increases by more than the change in the value of one's home. But it would be very difficult in practice to differentiate between equity release due to trading down and trading up. For example, a young married couple may have two homes - a small flat in London and a cottage in the country. They decide to have children and move into one large house. Is this trading up or trading down? Or consider the case of an entrepreneur who wants to take money out of his home and put it into a new company. He sells his house and buys business premises, with some rooms for accommodation, for a higher sum. Again, is this trading up or trading down? Even if it were possible to distinguish clearly between the two kinds of equity release, the notion of Bank of England officials checking individual mortgage loans by banks and building societies is mind-boggling.

There is, in any case, the wider and more fundamental question of why it matters that mortgage loans enable people to consume more. The idea that consumption is by itself improper and harmful has been heard over the ages from a variety of cranks, but so far no central bank has provided a persuasive theoretical rationale. The Bank of England - or, at least, some of its officials - seems not to like consumption, particularly when financed by bank loans. We have not been told why. In fact, personal sector bank borrowing was extremely helpful last year in sustaining consumption while real incomes were under pressure. Without it the recession would have been far worse and prospects for an economic upturn more remote than they currently are.

Of course, there is nothing particularly wicked about loans for consumption or particularly virtuous about loans for investment. The personal sector is in no sense less worthy - or a less fitting destination for credit - than the corporate sector. This was tacitly recognized last year when all restraints on conventional bank loans to persons for consumption were removed. Whatever the formal position, the December 1973 guidelines are defunct. Bank managers often require that equity in a house be collateral for consumption loans. As explained earlier, such loans are economically indistinguishable from using mortgage funds to take out equity from a home and spending the proceeds. Why is the Bank of England permissive towards one type of loan and disapproving towards the other? Its attitude seems muddled and illogical.

Perhaps the most disquieting aspect of the Bank of England's warning is its indifference to the principles of private property and personal freedom. As David Lomax remarked in his National Westminster Bank Quarterly Review article: 'A person's equity in a house is his or her own property, and provided the financial transaction is within the law there is no reason at all 
why he or she should not make use of his or her own equity. If the lending behaviour of certain institutions were clearly irresponsible and/or illegal, then appropriate regulatory or legal action should be taken against them. But that is a different matter from using extremely fragmented and hearsay evidence to build up a climate of criticism of lending institutions where there is no evidence at all from the economy itself, or from the movement of house prices, that any financial or economic disequilibrium is being generated.'

The liberalization of housing finance in 1981 was a welcome and logical continuation of the Competition and Credit Control reforms first introduced in September 1971. It will be followed by a minor boom in housing credit, with net mortgage advances likely to total $£ 13$ billion in 1982 compared with $£ 9.4$ billion in 1981 . The new funds will help stimulate private housebuilding and also, through the subsequent increased withdrawal of equity from the housing market, promote consumption. In the present depressed economic environment, both developments are fortunate. They should certainly not be deterred by artificial official restrictions, such as those hinted at in the Bank of England's warning to the banks in January this year. Equity withdrawal from housing has accounted for 55 per cent to 60 per cent of net mortgage advances over many years. It has permitted those quitting the housing market to consume or redispose of their wealth, a very normal and healthy characteristic of a free-market economy with extensive private ownership of property. Recent changes are certainly not a radical new departure. There does seem to have been some rise in the rate of equity withdrawal in 1982, probably because of trading down connected with the recession. It helps to explain the apparent anomaly of a sizeable rise in mortgage finance having little effect on house prices; it should certainly not be a cause of Government anxiety or official complaint.

The other message which emerges from our analysis is that the economy is very sensitive to interest rate changes. The linkages between interest rates, mortgage credit flows and private sector housebuilding are strong and identifiable. But much more can be said. Because interest rate reductions encourage credit flows through banks and building societies, they are often accompanied by an acceleration of house price inflation. This tends to be followed by a rise in the proportion of mortgage funds which home-owners use to withdraw equity. There is a consequent fall in the savings ratio and boost to consumption. Unfortunately, statistical evidence on the responsiveness of consumption to interest rate changes is weak, perhaps a reflection of the long period when the financial system was highly regulated and interest rates were not fully operative as allocative signals. 
If the economy does react powerfully to changes in the cost of money, there must be constraints on large interest rate reductions in the rest of 1982 . Credit is pouring into residential property at present. The associated rapid growth of bank and building society deposits is threatening the Government's sterling M3 and PSL2 targets. If interest rates come down quickly to 10 per cent or less, we can be confident that those targets would be unattainable and that an unsustainably vigorous upturn in housing market activity would develop. 
Tim Congdon - 9781788970709 Downloaded from PubFactory at 04/26/2023 01:33:19PM via free access 